\title{
CONFLICT OF LAWS IN THE UNIFORM COMMERCIAL CODE
}

\author{
MAx Rheinstein*
}

The new Commercial Code, like the several older laws which it is meant to replace, is recommended to the states as a uniform state law. While it is to be hoped that the Code will really become the uniform law of all the states and territories, it is by no means certain that this hope will be fulfilled and it can safely be predicted that there will be at any rate some period of time during which the Code will be in effect in some states but not in all. Since the Code's law is in numerous respects different from the present, there will arise problems of conflict of laws which must be taken care of in some way.

The sponsoring organizations also recommend that the Code be enacted as an act of Congress. In that case it will be necessary to demarcate the sphere of its application as federal law from that of the state laws, and that of its application as American law from that of the laws of foreign nations.

Finally, when the Act takes effect as state or federal law, it will, as in all cases of new legislation, be necessary to determine to what extent, if any, it should apply to pending transactions.

All these various problems are dealt with together in one Section of Article I of the Code, viz.; Section I-ro5, of which there are presented two versions, one to be inserted in the Act as a state law and the other to be inserted in it as an act of Congress.

Problems of conflict of laws are dealt with, furthermore, in some sections of the substantive articles of the Code, for instance $\$ 4$-I02 (bank's liability for action taken in the course of a bank collection), \$9-103 (lex rei sitae for secured transactions), or §ro-ro2 (lex rei sitae for bulk transfers).

The provisions of Section I-I05 on the Act's applicability in space were obviously inspired by the widespread dissatisfaction with the present conflict of laws. The draftsmen have not only chosen a mode of expression which, although only in form, is different from that usual for rules of conflict of laws, but they have also adopted a new policy. While ordinarily rules of conflict of laws, aiming at the ideal end of interstate and international uniformity of decision, ${ }^{1}$ are meant to connect a legal

*Dr. utr. iur. 1924, University of Munich. Max Pam Professor of Comparative Law, University of Chicago Law School.

${ }^{2}$ Cf. Herbert F. Goodrich, Handbook of the Conflict of Laws 7 (3d ed. 1949): "The outcome of litigation ... should not be changed by the fact that for one reason or another legal action is instituted somewhere else than .. . where the operative facts were located. Fairness to the parties requires that the fortuitous choice of a geographical place of suit should, as far as is possible, not vary the way in which the suit will be decided." 
problem with that legal order with which it appears to have the most significant contact, the rules of the Code are aiming at the widest possible application of the law of the forum, provided that the Act has been adopted there. Yet, this approach is not quite so novel as it looks. It has been tried before-and failed. ${ }^{2}$ Also, while it appears to be simple, it is likely to result in serious difficulties and complications. Section I-IO5 has thus met with strong criticism at several meetings of the American Law Institute and a warning against its adoption was expressed by a number of teachers of conflict of laws who were assembled at Ann Arbor, Michigan, in the summer of 1949 and, upon the motion of Professor Elliott E. Cheatham of the Columbia University School of Law, adopted the following Resolution:

Resolved, that the undersigned participants in the 1949 Institute of International and Comparative Law, Ann Arbor, Michigan, are of the opinion that Section I-Io5 (in both forms) of the May, 1949, draft of the Uniform Commercial Code, dealing with conflicts of laws, is unwise and should be omitted from the Code; and the Executive Secretary of the Institute of International and Comparative Law is requested to transmit a copy of this resolution to the President of the American Law Institute and the Chairman of Commissioners on Uniform Laws.

Apparently in view of the criticism encountered, ${ }^{3}$ the Section in question was rephrased twice. The version contained in the Proposed Final Draft has in some respects been improved over its predecessors, but it is still objectionable in so many and such basic respects that its adoption still appears to be inadvisable.

The Comment to Section I-I05 contains the following statement of policy: ${ }^{4}$

The provisions of the Section change pre-existing rules of the common law with regard to the application of the local or foreign rules of law to settle the rights of parties in a particular case. The purpose here is to apply the rules provided in this Act whenever the transaction has a sufficient contact with the state having the Act to make such an application reasonable and not arbitrary, while, at the same time, leaving the parties to a multistate or transaction involving foreign trade free to select any law which bears some normal point of contact with the contract instrument, document or security involved.

The statement that the Sections will result in applications of the Act which are always reasonable and not arbitrary, is the draftsmen's own value judgment, with which one may agree or disagree. The following analysis is presented in order to help the reader to form his own judgment.

In contrast to the earlier drafts in which one set of application rules was stated for all the various types of transactions of the Code, the present Draft contains separate provisions for Sales, Letters of Credit and Documents of Title (Sub-Section

2 See infra, p. 130 .

${ }^{3}$ For published criticism, see Rabel, Caldwell, Jordan, and Pugh, Choice of Law Under the Uniform Commercial Code, ro LA. L. Rev. 278, 29r (r950).

- Uniform Commercial Code, Proposed Final Draft \$r-105, comment 2 (Spring, 1950). The wording and punctuation are exactly those of the original, the italics are ours. The text of Comment 2 to $\$ x-105$, Federal Version, is practically identical. 
2), Commercial Paper and Bank Deposits and Collections (Sub-Section 3), Miscellaneous Banking Transactions (Sub-Section 4), Investment Securities (Sub-Section 5), and Secured Transactions and Bulk Transfers (State Version, Sub-Section 6). ${ }^{5}$ These provisions are followed by a Sub-Section on the parties' power to contract out the application of the Act, which is applicable to all types of transactions covered by the Code.

I. As far as it applies to Sales, Sub-Section (2) of the State Version reads as follows:

The Article on Sales (Article 2) ... appl[ies] whenever any contract or transaction within the terms of ... the Article is made or occurs after the effective date of this Act and the contract

(a) is made, offered or accepted or the transaction occurs within this state; or

(b) is to be performed or completed wholly or in part within this state; or

(c) relates to or involves goods which are to be or are in fact delivered, shipped or received within this state; or

(d) involves a bill of lading, warehouse receipt or other document of title which is to be or is in fact issued, delivered, sent or received within this state; or

(e) ... involves a credit issued in this state or under which drafts are to be presented in this state or confirmation or advice of which is sent or received within this state, or involves any negotiation within this state of a draft drawn under a credit.

The Federal Version is identical except that instead of "this state" it speaks of "federal territory" and that it is preceded by a Sub-Division rendering the Act applicable "whenever ... the contract is in or affects interstate or foreign commerce."

In so far as the Act is declared to be applicable whenever the contract is made or accepted or to be performed in $F^{7}$ the Act uses as points of contact the well-known contacts of "place of contracting" and "place of performance." The latter concept also recurs, at least in part, in the provision which declares the Act to be applicable when it "relates to or involves goods which are to be delivered ..." in $F$. The Act differs from present law, however, in using these contacts in cumulation rather than as mutually exclusive alternatives.

The other contacts are novel. Their effects will be illustrated by the following cases.

a. $B$ (buyer) and $S$ (seller) are businessmen residing in $X .^{8} B$, while vacationing in $F$, there mails to $S$ a letter containing the offer of a sale to be performed com-

\footnotetext{
"For security transactions and bulk transfers the Code contains special conflict of laws rules in $\$ \$ 9-103$ and 10-102(4), which are incompatible with the system of the general rules of $\$ \mathrm{r}-105$. It is probably for this reason that all reference to secured transactions and bulk transfers has been omitted in the Federal Version of $\S_{1-105}$. It should also be deleted from the State Version.

That term is defined in Sub-Section (7) to mean the District of Columbia and any territory or possession of the United States not having its own legislature.

"The symbol $F$ (forum) will be used here to designate a state which is the forum for the controversy to be decided and which has adopted the Uniform Commercial Code as its law.

${ }^{8}$ The symbols $X, Y$, or $Z$ will be used to designate a state in which the Act is not in effect, or a foreign country.
} 
pletely in $X$ (Sub-Div. a). F-law applies..$^{9}$ F-law would also apply if the offer was sent from $F$, but the contract itself was subsequently concluded in $X$, both parties being simultaneously present there.

b. In the course of a contract which has no contact with $F$, some goods are in fact shipped there, ${ }^{10}$ although under the terms of the contract they were to be shipped elsewhere. A court of the state where the goods were so shipped would have to apply its law.

So far the fact that even under the terms of the contract all the goods are to be shipped from a certain place has never been regarded as sufficient to subject the contract to the law of that place, unless the court would have found it possible to apply to that place the nebulous concept of place of performance. However, a court would hardly do so unless the contacts between the place in question and the contract as a whole were of a really substantial nature as indicated by other elements of the total situation. Under the Act it is to be sufficient for the application of the lex fori that, without any other factors connecting the contract with the forum, the goods are to be shipped, delivered, or received there. Indeed, the Section is so worded that it seems to be sufficient that the contract "relates to or involves" some part, however small, of the goods, which are to be shipped, delivered, or received at the forum.

The words of the text would seem to render possible or to require an even more startling result. Through an event occurring after the making of the contract and unforeseeable at the time, $F$-law would become applicable to all problems arising out of a contract, including the very problem of the contract's validity, which, at the time of its making, did not have with $F$ any contacts whatsoever. This subsequent event could be brought about not only by accidental circumstances such as mistake of the seller, shipper or carrier, or interruption or other dislocation of normal traffic facilities, but, so it seems at least under the text, by the deliberate act of a party. In a contract having all its contacts with state or country $X$, the seller might create for himself new defenses not available under $X$ law by simply in fact shipping or delivering some part of the goods in $F$. This result is so startling that it is hardly imaginable that it would ever be allowed by a court. But, by the text of SubDivision I-I05(2) (c) it seems to be not only allowed but required.

c. Similarly unforeseen and unforeseeable results would seem to follow from SubDivision I-I05(2) (d).

A contract is made in $X$ between $X$ parties and provides for the delivery of the goods in $X$. Unknown to the buyer, the goods are in storage in $F$. Advised of

\footnotetext{
${ }^{\circ}$ This case may, perhaps, not appear shocking to a devotee of the place of contracting theory, which renders decision depending upon the equally accidental place where the acceptance has been mailed. Such a reader should remember, however, that the "place of contracting" theory, when used alone, has at least the advantage of certainty which is impaired by the Act's cumulation of contacts.

There is one problem for which the law of the place of the offer might perhaps be considered as the proper law, viz., the problem of whether or not and, if so, in what manner an offer is binding upon the offeror. Cf. Renfrew Flour Mills v. Sanchagrin, 45 Que. 29 (K.B. I928).

${ }^{10}$ The meaning of the phrase "in fact delivered, shipped or received," as used in $\$$-I05(c), is not too clear. "Delivery" is defined in the Act only with respect to "instruments, documents, chattel paper [what is this?] and securities"; see $\$ 1-201(13)$. The other two words do not seem to be defined at all.
} 
this fact the buyer consents to performance by means of delivery, in $X$, of the warehouse receipt that was issued in $F$, perhaps subsequent to the making of the contract. While up to that moment it would have been obvious that $X$ law was the law of the contract, it seems that under the Act, $F$ law now becomes retroactively applicable. Again this result is unexpected. But it is provided by the Act.

Equally strange would be the result in the following case. One Frenchman in France purchases from another Frenchman goods covered by a bill of lading issued in an American state in which the Act is in effect. If a controversy should arise out of that sale and come up for decision in the state in which the bill of lading was issued, the court would have to apply the American Act.

d. Sub-Division (e) of Sub-Section (2) is equally apt to produce surprising results, as will be illustrated by the following hypothetical situations. A contract for the sale of goods has been made between $B$, a firm in Chicago, Illinois, and $S$, a firm in Hawaii. The goods are to be shipped from Hawaii to Chicago.

$B$ has obtained a credit from his bank in Chicago, while $S$ is working with a bank in San Francisco. The Act has not been adopted in Illinois or Hawaii; it is in effect in California, but it has not (yet) been adopted by Congress as a uniform regulation for interstate commerce. Under Sub-Division (e), the Act applies if there has occurred any one of the following events:

(I) the credit provides that $S$ 's drafts are to be presented to the bank in San Francisco;

(2) advice or confirmation of the credit was sent to $S$ by the San Francisco bank;

(3) S's draft, drawn under the credit, is sent by him to the bank in San Francisco and there indorsed and sent to Chicago;

(4) advice or confirmation of the credit was received in San Francisco by $S$ 's San Francisco agent; or

(5) the advising or confirming bank is in Honolulu, and there receives $S$ 's draft and indorses it to a correspondent bank in San Francisco, which, in turn, indorses it to a bank in Chicago. ${ }^{11}$

The application of $F$ law might be justified if it were limited to problems directly connected with the event occurring in $F$. It would be reasonable and not arbitrary to say that $F$ law shall respectively decide the validity of the issue in $F$ or the delivery in $F$ of a warehouse receipt or a bill of lading, or the validity of a negotiation in $F$ of a draft drawn under a letter of credit. But why should $F$ law apply to a sale which has with $F$ no contact other than that it "involves" a negotiation in $F$ of a draft drawn elsewhere under a credit issued elsewhere?

\footnotetext{
${ }^{11}$ Perhaps the last words of Sub-division (e) apply only where the negotiation of the draft in the forum was contemplated in the original contract between seller and buyer, or, perhaps, in the contract between the buyer and the issuing bank. The wording is so vague, however, that the interpretation of the text would seem to be thoroughly possible.
} 
Indeed, it seems that under the Act in any one of the situations discussed $F$ law would, in an $F$ court, determine, among others, the decision of every one of the following problems:

(a) whether the sale satisfies the statute of frauds;

(b) whether or not and, if so, to what extent, an offer was "firm";

(c) what is the meaning of such terms as F.O.B., F.A.S. or C.I.F.;

(d) what warranties of title and quality are implied in the sale;

(e) when and how title to the goods passes, or has passed, to the buyer;

(f) what constitutes a breach of contract and what are the parties' rights and obligations in the case of a breach.

What has $F$-law to do with any one of these questions? What businessman would, under the circumstances, expect at the time of contracting that any one of the problems mentioned might be judged by the law of $F$ ?

Under the principle underlying the case of Home Insurance Co. v. Dick, ${ }^{12}$ it is possible, or even likely, that in any one of the situations mentioned the application of $F$-law would be regarded as so unfair as to deprive the party adversely affected of his property without due process of law. In the just mentioned case the courts of Texas applied the Texas statute of limitations to an insurance contract which at the time of its making had all its contacts in Mexico and none in Texas. The Supreme Court, speaking through Mr. Justice Brandeis, held that this application of the Texas law constituted a violation of the due process clause of the Fourteenth Amendment to the Constitution of the United States. "In the case at bar, nothing in any way relating to the policy sued on, or the contracts of reinsurance, was ever done or required to be done in Texas. . . T Texas was therefore without power to affect the terms of the contracts so made. Its attempt to impose a greater obligation than that agreed upon ... violated the guaranty against deprivation of property without due process of law."13

The case, decided in 1930 , forms part of a whole series of decisions in which the Supreme Court seemed to embark, by using the due process clause of the Fourteenth Amendment, upon a conscious effort to restrict the states' freedom of developing their own choice of law rules and to strike down state practices which would not conform to the Court's own notions of a proper distribution among the states of legislative jurisdiction. ${ }^{14}$ During that period it looked, indeed, as if the Court would use the due process clause of the Fourteenth Amendment to develop for the allocation of legislative jurisdiction among the states a set of rules analogous to those developed by it for the allocation of procedural jurisdiction and jurisdiction to tax. In connection with the general reaction against "substantive due process," all these attempts of the Court are presently in disfavor. The decisions in which

1228 I U. S. 397 (1930).

${ }^{12} \mathrm{Id}$. at 408 .

${ }^{14}$ See especially New York Life Ins. Co. v. Dodge, 246 U. S. 357 (I918); Hartford Accident \& Indemnity Co. v. Delta \& Pine Land Co., 292 U. S. 143 (1934); Western Union Telegraph Co. v. Brown, 234 U. S. 542 (1913). 
the Court allocated among the states the jurisdiction to tax intangibles have been expressly overruled. ${ }^{15}$ Seemingly well established controls over procedural jurisdiction have been relaxed ${ }^{16}$ and the cases which seemed to allocate legislative jurisdiction along strictly defined lines have been succeeded by more recent decisions clearly indicating that the Court no longer finds in the due process clause a sufficient basis for such attempts. ${ }^{17}$ Yet, the Court has never relinquished all controls over state choice of law and there are indications that the court will not allow the application of its own law by a state which does not have an interest regarded as sufficient by the Court. ${ }^{18}$ The principle of the Dick case still stands and under this it would appear to be not only possible but probable that the Supreme Court will not allow a state to apply its own law to a contract which at the time of its making had no contacts with the state whatever and of which it could in no way be foreseen that it would be judged by the law of the state which later happens to be the forum.

2. With respect to Commercial Paper, the pertinent provision, Art. x-105(3), State Version, reads as follows:

The Articles on Commercial Paper (Article 3) and Bank Deposits and Collections (Article 4) apply whenever any contract or transaction within the terms of any one of the Articles is made or occurs after the effective date of this Act and the contract

(a) is made, offered or accepted or the transaction occurs within this state; or

(b) is to be performed or completed wholly or in part within this state; or

(c) involves commercial paper which is made, drawn or transferred within this state.

The introductory clause to this Sub-Section is anything but clear. What is the meaning of the words "any one of the Articles"? Do they refer back to the two Articles just mentioned in the sentence, i.e., Articles 3 and 4; or do they refer to all the nine substantive Articles of the Act, i.e., Articles 2 to ro? If the provision were meant in the former sense, one would expect to find the words "within the terms of these Articles" rather than the words actually used. The grammatical meaning of the latter would seem to point in the direction of a reference to all the articles of the Act. The effects of such a meaning would be peculiar. The Act's provisions on Commercial Paper would apply whenever there occurs any contract that is to be performed or completed in the forum, and a problem of commercial instruments law arises in some connection with that contract, irrespective of whether or not that problem, or the paper itself, has any contact with the forum.

But even if the introductory words of the Sub-Section are to be read in the narrower sense, the provisions are hard to understand.

\footnotetext{
${ }^{16}$ Curry v. McCanless, 307 U. S. 357 (1939); State Tax Commission v. Aldrich, 316 U. S. 174 (1942); Greenhough v. Tax Assessors of City of Newport, 33I U. S. 486 (1947).

${ }^{16}$ See International Shoe Co. v. State of Washington, 326 U. S. 310 (I945); Travelers Health Ass'n v. Commonwealth of Virginia, 339 U. S. 643 (1950).

${ }^{17}$ Alaska Packers Association v. Industrial Accident Comm'n, 294 U. S. 532 (1935); Hoopeston Canning Co. v. Cullen, 318 U. S. 313 (1942); Travelers Health Ass'n v. Commonwealth of Virginia, supra, note 16 .

${ }^{18}$ See Alaska Packers Ass'n v. Industrial Accident Comm'n, supra, at 543; Hoopeston Canning Co. v. Cullen, supra; Order of United Commercial Travelers v. Wolfe, 33 I U. S. 586 (1947).
} 
Articles 3 and 4 are declared to be applicable "whenever any contract" is "made ... or to be performed ...." within the forum, or whenever it "involves commercial paper" having a certain contact with the forum. What is meant by "contract"? Although accepted canons of legislative technique would lead one to expect that a term used in the introductory clause to a section has the same meaning throughout the section, it seems to be impossible to find a meaning of the word "contract" that could be applied equally to Sub-Divisions (a) and (b) and to Sub-Division (c).

A commercial paper, especially a negotiable instrument, ${ }^{19}$ is not in itself a contract or a transaction but a piece of paper which evidences or "embodies" a contract or a transaction or a whole series of contracts and transactions. Sub-Divisions (a) and (b) of Sub-Section (3) seem to be concerned with those single contracts and transactions which occur to a commercial paper during the course of its circulation. However, in connection with Sub-Division (c) the word "contract" must have a broader meaning, a meaning so broad, indeed, that it must "involve" the entire paper as such. This grammatical requirement would seem to indicate that in connection with Sub-Division (3) the word "contract" has the same meaning which is ascribed in the Comment to the Title to the Act ${ }^{20}$ to the word "transaction," viz., that total chain of business activities of which a particular contract is a part.

When the first meaning is ascribed to the word "contract" in connection with Sub-Divisions (a) and (b), it seems that under these provisions, the Act does not apply to the negotiable instrument as a whole, but only to that particular contract or transaction that occurred in the forum, ${ }^{21}$ or to that particular "contract"22 which "is to be performed wholly or in part within" the forum. In so far, the Code seems to approximate the approach now uniformly followed both in this country and abroad, under which, for purposes of choice of law, every transaction concerning a negotiable instrument is viewed independently from the others concerning the same instrument. ${ }^{23}$ An important difference from the present law lies, however, in the fact that under Section I-I05 the law of the forum is to be applied not only when the forum is the place of contracting but also when it is the place of performance (or even of just a part of the performance), while at present it is not definitely settled whether problems arising out of a promise contained in a negotiable instrument are to be decided under the law of the place of contracting or under that of the place of performance. In most jurisdictions that question is so widely open, indeed, that the courts may choose in each case as they please; and since both terms, place of contracting and place of performance, are vague, the contacts available to the courts are about as numerous as those listed in the Code. Only, at present the court may

${ }^{10}$ For the definition of the term, see U. C. C. $\$ 3-104$.

${ }^{20}$ See pp. 2 and 6 of the r 950 Draft.

21 But quaere, where does a making, an indorsement, or an acceptance, etc., occur? If a negotiable instrument is endorsed in $A$ and sent to the indorsee in $B$, is it endorsed in $A$, or in $B$, or partially in $A$ and partially in $B$ ?

${ }_{22}$ Quaere, why is the word "transaction" appearing in Sub-Division (a) not repeated in Sub-Division (b)? The omission might be regarded as indicative of an intention to have, under Sub-Division (a), the Act apply only to that part of an indorsement, etc., which occurs within the forum.

23 The so-called principle of independence. 
choose a foreign contact as well as the forum and in fact the courts tend to choose that law with which they feel that the transaction has the most essential connection. Under Section I-I05(3), however, the Act must be applied if any one contact exists with the forum even though the court may feel that it is less essential than others with a foreign jurisdiction.

The greatest difficulty, however, is created by the fact that the principle of independence, established in Sub-Divisions (a) and (b), is coupled with the incompatible rule of Sub-Division (c). As far as that provision can be understood at all, it seems to require the application of the lex fori to the entire chain of transactions in which the commercial paper is "involved" if that paper is "made, drawn or transferred within" the forum. If so understood, the provision would mean that the lex fori applies to every problem arising out of that paper and, beyond that, even to every problem arising out of every sale, credit, or any other transaction in which the paper appears in some way. If some payment is made by means of a commercial paper that has just once been negotiated in the forum, the forum's law would thus apply-even retroactively - to every problem arising between the parties to the underlying sale, even though that sale has no contact whatsoever with the forum. This result is so incredible that it throws grave doubts upon our interpretation of SubDivision (c) of Sub-Section (3). But it is difficult to see in what other way this provision could be interpreted.

3. The policy and technique appearing in the Code's choice of law rules on sales and commercial paper equally appear in its choice of law rules on the other transactions within its scope. Their presentation and analysis would not add to, or modify, the impression that many of those contacts between a transaction and the forum which under the Code require the application of the forum's law to the entire transaction are so tenuous and often so unforeseeable that they can hardly be regarded as "sufficient to make such an application reasonable and not arbitrary." In certain situations the provisions of the Act produce such arbitrary results that their constitutionality is subject to serious doubt.

4. However, so far we have not yet spoken of that feature of the Act which may easily result in the gravest disturbances of interstate and international trade.

One of the most firmly established and most generally recognized principles of the conflict of laws is that of the application of the lex rei sitae to problems concerning the title to corporeal things. The problems of determining whether or not and, if so, to what extent title has been transferred, encumbered, or disencumbered by a transaction purporting to do so, or by some other event alleged to have done so, is decided under the law of the place at which the thing was physically located at the time of the transaction or event in question. ${ }^{24}$ If we wish to know whether a transaction or an event that took place at II:23 a.m. of July I, 1950, resulted in a transfer from $S$ to $B$ of the title to a chattel, or in the creation for $S$ of a security interest in the

\footnotetext{
${ }^{24}$ See Restatement, Conflict of Laws $\$ \$ 255-260,265-267,272-274,279-281,283,284,286,294$ (1934).
} 
chattel, or in any other alleged modification of the title situation of the chattel, we consult the law of the place at which the chattel was located at II:23 a.m. of July I, I950. This rule is universally recognized today not only in this country but also abroad. ${ }^{25}$ This striking unanimity finds its reason in the imperative demand of business for security. He who considers the purchase of a chattel or the extension of credit upon the basis of a chattel security, must have a way of ascertaining whether the title is in the would-be seller, pledgor, mortgagor, or debtor and whether and, if so, to what extent, the title is encumbered by security or other limited interests of third parties. Any attempt to ascertain the title situation requires both an investigation of the facts and an evaluation of the facts under the rules of some system of law. No such evaluation can be made unless the legal system to be consulted is clearly determined; it must be one system and it must be one that can be determined with ease and without complicating difficulties. While it may be wise policy in the conflict of laws to uphold an alleged contract when it is valid under just one of several laws, with respect to title problems the law to be consulted must be determinable unequivocally. Title must be found to be either in $A$ or in $B$ and little help could be derived from a rule which would mean that under $X$-law title is in $A$ and under $Y$-law in $B$. Furthermore, the contact determinative of the relevant law must be as simple as possible. Both requirements are fulfilled by the rule of lex rei sitae. If I wish to know whether the man who has offered to sell me his car has the full and unencumbered title, I look to the law of the place where the car was located at the time of the event which my seller alleges to have given him title, and if I wish to know whether at some subsequent time his title has been lost or encumbered I investigate whether there has happened any event that would have resulted in such consequences under the law of the place or places where the car happened to be. The same inquiries will be made if the Metropolitan Museum of Art wishes to find out whether a good title to the offered Rembrandt is in the offeror, or by a bank when it wishes to know whether it can safely accept a check, bill, note, warehouse receipt, stock certificate, or similar instrument delivered or endorsed to it.

As a matter of fact, the certainty and simplicity of the rule of lex rei sitae is of peculiar importance with respect to negotiable instruments and negotiable title documents. Speed is essential in their circulation. The easier the investigations which a careful prospective transferee has to make, the greater will be their commerciability. It has thus become one of the essential elements of negotiability that the claim or claims against the signer or signers are said to be "embodied" in the paper in the sense that any valid transfer of title to the physical piece of paper automatically

\footnotetext{
${ }^{25}$ See Arthur K. Kohn, Comparative Commentaries on Private International Law, or Conflict of Laws 236 (1937); ERnest G. LoRenzen, Cases and Materiats on the Conflict of Laws 594 (5th ed. x946); M. Wolf, in 4 SchLegelberger, Rechtsvergleichendes Handwoerterbuch 390. The only exceptions seem to be Spain (Código civil, art. Io), Cuba (Código civil, art. Io), and Quebec (Code civil, art. 6), whose Codes still adhere to the once general maxim of mobilia sequntur personam.
} 
carries with it the transfer of the claim or claims. ${ }^{20}$ Since it is thus the transfer of the physical substratum which is relevant in the assignment of the claims, it follows that for purposes of the conflict of laws, the transfer of the claims "embodied" in a negotiable instrument is looked upon as the transfer of a chattel and that, therefore, the effectiveness and the effects of an alleged transfer are judged under the lex rei sitae, i.e., the law of the place where the paper was physically located at the relevant time. ${ }^{27}$ For the analogous purpose of facilitating the circulation of goods, an analogous situation exists for documents of title. Transfer or encumbrance of the title to the paper is to imply the transfer or the encumbrance of the goods ${ }^{28}$ and the location of the title to the paper cannot be ascertained with the required ease and speed unless it is subject to the rule of lex rei sitae.

This entire system, which is the only one suitable to needs of modern business, will be overthrown if the Draft Uniform Commercial Code is enacted into law. By failing to separate, as is now universally done, the title problems from the contract problems, the Code makes the former dependent upon the latter. If a title problem arises in the courts of a state which has adopted the Act, it will have to decide it under its own law whenever the contract has with the forum any one of the numerous and often tenuous contacts established in the Act, even though the goods may never have been in the state. The result may be not only unfair but unconstitutional.

Let us assume that in a sale of ascertained goods the only contacts with $F$ are that the offer was made there and that it happens to be the forum, but that the goods neither are nor have ever been in $F$. If it is controversial whether title to the goods has passed from the seller to the buyer at the time of the making of the contract, the court would have to apply the Act and to hold under Section 2-40r (2) that no transfer of title has occurred at that time. However, if the goods at the time of the making of the contract were in a state or country where the Act is not in force and under whose law title passes with the making of the contract, as is the case, for instance, under the present Uniform Sales Act or the French Civil Code, ${ }^{20}$ all courts which are not bound by the Act's conflicts rules will hold that title has so passed. Thus for all these courts title is in $B$, while for the courts of $F$ it is in $S !$ It may well be held that such a decision of the $F$ courts would constitute a taking

${ }^{20}$ See $\$ 3-201(x)$ of the Act: "Transfer of an instrument vests in the transferec such rights as the transferor has therein. ..."

${ }^{27}$ Embiricos v. Anglo-Austrian Bank, [1905] I K.B. 677; United States v. Guaranty Trust Co., 293 U. S. 340 (I934).

${ }^{28}$ See $\$ 7-502(\mathrm{r})$ of the Code: “. . . a holder to whom a negotiable document of title has been duly negotiated acquires thereby:

(a) perfect title to the document;

(b) perfect title to the goods; ...."

But query whether this world-wide principle has been changed by $\$ 2-401(2)$, which provides that under a sale "unless otherwise explicitly agreed title passes to the buyer at the time and place at which the seller completes his performance with reference to the physical delivery of the goods .... even though any documents of tille are to be delivered at a different time or place. . . ."

${ }^{90}$ Art. 1583 . 
without due process of law of the property of $B$, or of a creditor of $B$ 's who has attached the goods, or with whom $B$ has made a transaction for the grant of a security interest.

Similar situations may arise with respect to commercial paper. Assume that a negotiable instrument that is payable in $F$, has been negotiated in $X ; F$ law will have to determine the effectiveness of the alleged transfer. If we assume that $X$ is a European or Latin-American country, where title can be acquired by a bona fide endorsee under a forged indorsement and in a stolen paper, ${ }^{30}$ the transferee would be retroactively deprived of his title, whenever his right would become litigious in $F$.

The rigor of the rule is only insufficiently mitigated by Section 4-IO2(2), which very sensibly provides that "notwithstanding the provisions of Section I-105 the liability of any bank for any action taken in the course of a bank collection is governed by the law of the place where the bank is located ..." The policy of this provision, which will exclude decisions so unfair against foreign banks as that rendered in the case of Weismann v. Banque de Bruxelles ${ }^{31}$ should constitute the rule rather than the exception. In all probability the obviously inappropriate results of Section I-IO5(3) would be held to be incompatible with the due process clause of the Fourteenth Amendment.

\section{II}

In addition to the problems of policy and basic legislative technique discussed so far, Article I-I05 present some problems of formulation which, unless remedied, may produce trouble.

I. In the Federal Version of Section r-ro5 every one of the Sub-Sections 2 to 5 contains a clause which renders the American Uniform Commercial Code applicable to every transaction of the kind in question

"whenever the contract is in or affects interstate or foreign commerce."

We have to leave it to constitutional experts to judge the appropriateness of the words intended to bring under the Act all those "interstate" transactions which can be brought under it under the commerce clause of the Constitution of the United States. Our concern is solely with that part of the clause which subjects to the American Act any contract which "is in or affects foreign commerce." For this country a contract would seem to be one in foreign commerce not only when it occurs between a foreign country and the United States, but also when it occurs exclusively between foreign countries and conceivably even when it occurs totally within one foreign country. If the Act were to become an Act of Congress with Section I-I05 in its present wording, it might well be interpreted to mean that an American court would have to apply the American Commercial Code to a sale made in France between a Frenchman and a Belgian, an indorsement of a negotiable

\footnotetext{
${ }^{30}$ Geneva Convention on Bills of Exchange, of 1930, Art. I6; Geneva Convention on Checks, of 1930, Art. 21 .

${ }^{31} 254$ N. Y. 488, I73 N. E. 835 (1930).
} 
instrument made by a Mexican to a Guatemalan in Mexico, the negotiation in Rome of an Italian investment security between an Italian and a Greek, a bank deposit made in Amsterdam by a Dane with a Dutch bank, or a letter of credit issued in Buenos Aires by an Argentinian bank to an Argentinian client to be used by him in a transaction with a Brazilian. Clearly, such decisions would be absurd. Perhaps, or probably, the courts would find ways to avoid them; but they would do so only by either going against the clear text of the Code or by declaring it unconstitutional under the Fifth Amendment. A rule, which would require American courts to apply American law to every transaction occurring in foreign commerce might also induce reprisals on the part of other countries. Quite probably, the result was not intended by the draftsmen of the Code, but it seems to be required by the wording which cannot be left as it reads now.

2. Similar effects are apt to be produced in consequence of the peculiar wording of Sub-Section (7) of the State and Sub-Section (6) of the Federal Version.

Under this Sub-Section the parties are allowed to agree that their rights and duties shall be "governed" by the law of some jurisdiction other than the forum whenever a contract, instrument, document, or security has points of contact with one or more [jurisdictions] in addition to [the forum]; in the absence of such agreement [the] Act governs.

That means that the lex for i is to "govern" all transactions for which the parties have not stipulated otherwise and which have contacts with both the forum and one or more other jurisdictions. If understood literally, that provision would render superfluous all preceding ones. Perhaps, the draftsmen intended to render the Act applicable only to those multistate transactions which have with the forum some one of the contacts mentioned in the preceding Sub-Sections of Section I-105. But the text does not read so; perhaps the draftsmen believed the limitation to be superfluous because the contacts with the forum in the preceding Sub-Sections are already so broad and so numerous as to subject to the lex fori practically every transaction having some contact with the forum. At any rate, the provision neatly summarizes the spirit of the Act. Being the best of all possible codes of commercial law, it ought to apply to all transactions which can possibly be brought under its scope. Such an idea is novel in modern times. Quite possibly, the lawyers of some other country regard their codes as the best possible ones in the world; but, at least as far as it is known here, none has challenged the world by declaring its laws applicable to all transactions which have some point of contact with it. Clearly, the provision cannot be allowed to become law.

3. In several places Article I-r05 makes provision for the case where a contract "or transaction" is made or "occurs" in a certain contact with the forum."

${ }^{32}$ Sub-Section (2): The Articles on Sales, Letters of Credit, and Documents of Title apply "whencver ... the contract ... . is made or the transaction occurs" within the forum. The same is said in SubSection (3) as to the articles on Commercial Paper and Bank Deposits and Collections, in Sub-Section (4) as to the Articles on Miscellaneous Banking Transactions, and in Sub-Section (5) as to the Article on Investment Securities. 
What is the meaning of the words "transaction" and "occurs"? 33

Does the word "transaction" apply to every step taken by either party in the course of the performance of the contract, e.g., the allocation by the seller of unascertained goods to the contract, shipment of the goods or of papers representing them, tender, delivery, inspection or acceptance of the goods, or tender or acceptance of the price?

In that case, does the Act apply only to the transaction in question or to the contractual relation as a whole? In the former case, different aspects of the same contractual relation may have to be judged by different laws which may be incongruous with each other; in the latter the Act would be applied to a contractual relation which may have only slight contacts with the forum. Neither result would be desirable or consonant with the general policies of American conflict of laws.

If, on the other hand, "transaction" has the same meaning as contract, the word is supererogatory and misleading.

Possibly, the word "transaction" may have a broader meaning than the word contract, viz., that total chain of business activities of which a particular contract for sale is a part. ${ }^{34}$ In that case the provision would be particularly undesirable as it might make the application of the lex fori to a contract for sale dependent upon factors which may be totally unrelated to that particular contract.

The indefiniteness of the noun "transaction" is aggravated by the use of the verb "occur," the meaning of which is completely obscure.

4. Sub-Sections (2), (3), and (5) declare the Act applicable "whenever the contract is to be performed or completed wholly or in part within" the forum. What is the difference between "performing" and "completing" a contract? The latter term is unusual in legal parlance. Where it is used at all, it is either in the context of contractual clauses providing that the price is not to be paid until the contract, i.e., usually the work ordered, is completed, or it is used with reference not to the performance but to the making of a contract. If in Section I-IO5 the word "to complete" is to be synonymous with "to perform," why is it then used at all? If it is to have a different meaning, it should be explained.

5. Sub-Section (2)(d) speaks of a contract which "relates to or involves" goods having a certain contact with the form. Sub-Sections (2) (e), (3), (4), and (5), on the other hand, speak of a contract which "involves" certain instruments. What is the difference between the two verbs? What do they mean? Why is the phraseology of Sub-Section (2) (d) different from that of the others?

6. Article $\operatorname{I-IO5}(2)(e)$, of which we had already occasion to speak, ${ }^{35}$ in addition to the problems already discussed, also presents a peculiar problem of formulation. In connection with the initial clause of Sub-Section (2), the provision reads as follows:

${ }^{33}$ Cf. p. 121-122, supra.

${ }^{34}$ It is in this sense that the word is used in the Comment to the Title of the Act; see pp. 2 and 6 of the r950 draft; supra, p. I2I.

${ }^{30}$ Supra, p. $1 \times 8$. 
The Articles on Sales (Article 2), Letters of Credit (Article 5) and ... Documents of Title (Article 7) apply whenever any contract or transaction within the meaning of any one of the Articles is made or occurs after the effective date of this Act and the contract

(e) is an application or agreement for a credit made, sent or received within this state, ....

What is the meaning of this phrase?

We have to ask how "the contract" can ever be "an application" for a credit. As long as an application for a credit is not accepted, it is not a contract. Thus, if read literally, the part of the Section referring to applications for credit does not make sense. If it is to have any meaning, the provision must probably be read as if it said that Articles 2, 5, and 7 apply "whenever ... an application for a credit is made, sent or received within" the forum. If so read, the provision is superfluous, however, because it merely repeats what has been said already in Sub-Division (a) of Sub-Section (2), and the same statement can be made about Sub-Division (e) in so far as it deals with an "agreement for a credit made, sent or received within" the forum. Such an agreement simply is a contract "made, offered or accepted" in the forum within the meaning of Sub-Division (a).

\section{III}

We trust that our analysis of the conflict of laws provisions of Section $\mathrm{r}$-ro5 has shown that their adoption cannot be recommended. But what shall be done?

There are three possibilities:

First: To rewrite the provisions so that they constitute a set of rules in consonance with business needs and sound policies; or

Second: To omit in the Code all general rules on its applicability and thus to revert to the common law rules of conflict of laws; or

Third: While generally leaving to the common law the problems of the Act's applicability, to insert in the Code a few provisions in order to clarify the common law rules where they are in doubt, or to modify or simplify them where they are unsatisfactory.

I. The first method, i.e., that of re-writing the Act's provisions on its applicability, would be so formidable a task that it could hardly be undertaken at the present stage.

As we have tried to show, many of the objectionable features of the present provisions of the Act are caused by the fact that an attempt has been made to regulate problems of great complexity and delicacy by a few statutory rules of broad, general formulation. Even though the draftsmen have carefully avoided letting their rules appear as rules of conflict of laws, they are in fact so-called unilateral choice of law rules. $^{36}$ As such they partake of all the difficulties with which the formulation, especially the statutory formulation, of conflicts rules has been beset. Of the numerous foreign attempts to codify conflict of laws, none has been successful. The reason lies primarily in the youthful age of that branch of the law. In the

${ }^{38}$ Cf. I Ernst Rabel, The Confict of Laws: A Comparative Study 26 (1945). 
Anglo-American countries the choice of law technique did not appear at all before the late eighteenth century; its application remained rare until well into the nineteenth century; it did not become a generally taught law school course until the last few decades; and even today the average lawyer shys away from conflicts problems as from terra incognita. On the European continent, the conflict of laws has had a venerable history of more than seven hundred years. However, during almost all of that long time, it has been the subject matter of unsolved controversies and whatever stability had been achieved broke down in consequence of certain basic features of the world's political and legal organization. Both the Italian and the French schools of conflict of laws elaborated their doctrines as parts of a legal system superior to all those local laws whose fields of application were to be demarcated from each other. The first attempts to view the rules of conflict of laws as parts of these very local laws were made by the Dutch jurists of the seventeenth century. But they failed to recognize all the implications of this fundamental innovation. The rules formulated by them were still repetitions of those worked out by their predecessors, especially Bartolus and D'Argentré. In England, and later in the United States, these rules came to be known in the condensed epitome of Ulrich Huber. On the continent, all efforts finally ended in the morass of the late statutist theory, the complete unworkability of which was demonstrated in the early I840's by von Waechter. ${ }^{37}$ An effort at a new beginning was made by Savigny, ${ }^{38}$ but even he could not entirely free himself from the fetters of the century-old tradition. Ever since his days the conflict of laws has been the favorite domain of theorists, almost all of whom believed that all its problems could be solved through the formulation of a few broad general rules and principles. The contradictions between their various theories have created a state of uncertainty which has been aggravated by the inevitable efforts of the courts to decide individual cases upon their real merits. However, the compulsion felt by the courts to express their decisions in terms of the general rules has deprived many of these rules of any determinable certainty. Only in very recent years has the insight been expressed that the complex problems of the conflict of laws cannot be adequately expressed in some few lapidary maxims. Both in this country and abroad this insight has produced proposals to do away with all choice of a law rules and to give the courts complete freedom to decide all conflicts cases upon their individual merits. ${ }^{39}$ Such proposals, while understandable as reactions against the present confusion, would replace it by even greater uncertainty and unpredictability.

\footnotetext{
${ }^{37}$ Ueber die Collission der Privatrechtsgesetze Verschiedener Staaten, 24 ARCHV FUER DIE GIVILISTISCHE Praxis 230 ( 1843 ); 25 id. at I.

${ }^{38} 8$ SySTEM DES HEUTIGEN ROEMISChEN Rechts (Guthrie transl. 2d ed. r880).

${ }^{30}$ Cavers, A Critique of the Choice of Law Problem, $47 \mathrm{HARv}$. L. Rev. I73 (1933); Fraenkel, Der Irrgarten des internationalen Privatrechts, 4 ZEIrschrIFT FUER AUSLAENDISCHES UND INTERNATIONALES Privatrecht 239 (1930); Hijmans, Algemeene problemen van international privaatrecht Zwolle (I937); for criticism of this view, see especially DE Nova, Soluzione DEL ConfLitTo di LEGG E REgolaMente confacente del rapporto internazionale. Studia Ghisleriana, Series i, n. 5 (Pavia I947).
} 
The proposals of the Draft Code constitute another attempt to free commercial transactions from the over-refinements, complexities, and uncertainties of the present conflict of laws. Conflict problems are practically eliminated by simply subjecting to the lex fori all transactions which have some connection with the forum. That at least is the effect of the detailed provisions of Section I-I05, and it would have been more simple and more candid to state that idea in just that way. It is, indeed, so stated in sub-section (7) of the State and sub-section (6) of the Federal Version, but probably against the intention of the draftsmen. ${ }^{40}$ The idea simply to apply the law of the forum to all controversies is not new, but wherever it has occurred in any society of any complexity, it was supplemented by some device to eliminate from the domain of the lex fori the decision of cases for which, because of the predominance of foreign contacts, the application of the lex fori would have been unfair. In Rome such cases were assigned to the jurisdiction of the praetor peregrinus, who would decide them under izs gentium rather than under the peculiarly Roman ius civile. In the Middle Ages controversies arising out of inter-local commerce were the domain of the Courts Merchant and the world-wide Law Merchant rather than of the local courts and the local law; and for those cases which could not come before the Courts Merchant, the scholars and courts of Italy invented that very technique of choice of law from which our modern conflict of laws has been derived. In England a case could not be decided by the common law courts unless all the facts had occurred in England. Cases of international character were decided by the Courts Merchant, the Council, and other agencies. When, after the decline of these agencies, they were brought into the common law courts through the use of the fiction that the foreign place was located in England, it was soon felt necessary to adopt the continental method of applying foreign law in accordance with those conflicts rules that had been formulated by the Dutch lawyers of the sixteenth and seventeenth centuries. ${ }^{41}$ A return to the old principle of indiscriminate application of the lex fori would soon turn out to be as unworkable as the older attempts were, even if it were mitigated by the exclusion from it of the cases which do not have any contact at all with the forum.

The desire to free commercial transactions from the vagaries of the present conflicts law is understandable, but it cannot be fulfilled in the way proposed by the Draft Code.

The exigencies of business and social life require a different approach, viz., that of breaking up the old over-generalizing rules and the formulation of new, more refined and more detailed rules which will assign the decision of every legal problem to that legal system or systems with which it has, in the light of the forum's policies, its most essential contact or contacts. The type situations that have to be connected with a certain law must be formulated much more narrowly than they

${ }^{10}$ See stupra, p. 126.

¿In the English developments, see A. N. Sack, Conflicts of Laws in she History of English Lasv, in 3 LAW: A Century of Progress, I835-x935 342 (1937). 
have been so far. ${ }^{42}$ We are no longer justified in saying that torts are governed by one law or contracts by some other. Special rules of spatial reference must be formulated for such narrower problems as, for instance, that of determining whether a certain conduct is tortious, whether one person is liable for the conduct of another, whether one person liable for tortious conduct is entitled to contribution from another; or for the problems of determining which law's formalities must be complied with in order to conclude a valid contract, which law shall define what constitutes a breach of contract, which law shall define the remedies available in case of a breach, etc. A further breakdown will be necessary for different kinds of transactions. A choice of law rule appropriate for insurance cases may be inappropriate for a contract for services, a surety contract, or a contract for transportation by rail, by highway carrier, by inland waterway, by sea, or by air. ${ }^{43}$

Obviously, this task of reformulating the choice of law rules in accordance with the exigencies of all conceivable type situations is gigantic. It has hardly been recognized and still less begun. Everywhere we find a feeling of dissatisfaction with present law, a stirring, and promising beginnings. But the time is not yet ripe for statutory formulation. The situation is strikingly illustrated by the groping vacillations and uncertainties that have been encountered in all recent efforts to establish conflict of laws rules by international convention for even so seemingly simple problems as those appearing in the sale of goods, not to speak of the greater complexities of negotiable instruments or letters of credit. ${ }^{44}$

2. What has been said would all seem to lead to the conclusion that it might be best for the Uniform Commercial Code to omit all conflict of laws rules. The courts would then simply have to apply the existing methods which, underdeveloped as they are, especially from the theoretical point of view, have usually resulted in fairly sound decisions. That approach would, of course, be the easiest way out and it might be the most sensible one in view of the almost insurmountable difficulties of formulating a complete set of rules applicable to all conflict of laws problems that may turn up in connection with the Code. Their formulation would be a timeconsuming task which would require the cooperation of a considerable number of experts. It could not be achieved at all, if the sponsors of the Code should press for its early adoption.

Omission from the Code of all conflicts rules might be advisable for another reason.

The Act, although called the Uniform Commercial Code, is not a comprehensive codification of the entire law of commercial transactions. It regulates those problems

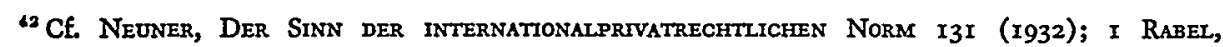
Confuict of Laws 92 (1945). See also Neuner, Policy Considerations in the Conflict of Latus, 20 CAN. B. REv. 479 (I942).

${ }^{43}$ Cf. 2 Rabel, Conflict of Laws 480 (1948).

" $C f$. Rabel's well considered judgment on various recent foreign attempts to codify the conflict of laws as to contracts in a few broad rules. He properly calls them "the unconvincing product of divination rather than inquiry." RABEL, op. cit. supra note 43 , at 483 . 
which are embraced within its terms, but it is supplemented by the entire body of "law and equity, including the law merchant and the law relative to capacity to contract, principal and agent, estoppel, fraud, misrepresentation, duress, coercion, mistake, bankruptcy, or other validating or invalidating cause."45 According to Section I-I05, the courts of $F$ would have to apply the Act whenever there exists with $F$ any one of the contacts enumerated in the various provisions of the Section. But which law will the courts of $F$ have to apply to the solution of a problem which arises in connection with such a transaction, but which is not covered by the terms of the Act, such as, for instance, a problem of capacity, agency, or misrepresentation? Assume that the transaction in question is a contract for sale "made" in $X$, but "proposed" in $F$ or relating to goods shipped in $F$; assume, furthermore, that under the rules of conflict of laws as generally recognized in $F$, problems relating to the validity of a contract are to be determined under the law of the place of contracting. In such a situation, the courts of $F$ would have to apply the Act to all problems which are regulated by its provisions, but the law of $X$ to all other problems relating to the validity of the contract. Is such a situation advisable and compatible with good business practice? Is it ever feasible in such a way to dismember a transaction and to apply different laws to problems which may be so closely connected with each other that their determination under different laws may well lead to incongruities?

But if in spite of all the difficulties, it should be decided that the Code ought to contain provisions on its applicability to multi-jurisdictional transactions, attention ought to be paid to the various attempts which which have been made in the recent past to work out on an international scale choice of law rules for commercial transactions. The most remarkable attempt of this kind made for sales is the Draft Convention on Conflict of Laws concerning Sales of Chattels. It is the last of various successive drafts prepared for and by the Sixth Hague Conference on Conflict of Laws (I928), ${ }^{46}$ and it was prepared subsequent to that Conference by a

${ }^{45}$ See $\$ I$-ro3, U. C. C. (Spring, r950).

${ }^{6}$ The earlier drafts and the discussions of the Conference are published in Conffrence de LA HAYE de Droit International Privt. Actes de la Sixième Session 376 et seq. (1928). For the extensive documentation, especially the governmental replies to a questionnaire prepared by the Royal Government of the Netherlands, see Conffrence de LA HAye de Droit International. Prive; Documents Relatips A LA Sixième Session (I928). For discussions of the work of the Conference, see L. Strisower, Das Internationale Privatrechtes Kaufvertrages in den Entwïrfen der Sechsten Haager Privatrechtskonferenz, 7 Zeitschrift für auslandisches und internationales Privatrecht 318 (1931); J. de la Morandière, La sixieme Conference de La Haye, Journal DE DRoIT INTERNATIONAL PRIVE (CLUNET) 28I (I928); B. C. J. Loder, La Sixième Conférence de droit international privé, Transactions of the Grotius Society 7 (1929); Altstoetter, Die Beratungen der 6. Hanger Privatrechtskonferenz. 1928 Junistischi WOCHENSCHRIFT 1987; Gutzwiller, Das International privatrecht der Haager Konferenz, 2 SchwetzeRISCHES JAFRBUCh FÜr INTERNatTonales ReCht 48, 8I (I942). Cf. also the comprehensive discussion by A. Bagge, Les conflits de lois en matière de vente de biens meubles corporels, 25 REcuEIL DES Cours DE L'ACADÉMTE de DroIt INTERNATJONAL 125 (I929).

The Hague drafts were preceded and influenced by the work of the Institut de Droit International, published in 33 ANNUATR DE L'INSTITUT DE DROIT INTERNatIonat (1927), vol. 2, p. 875, vol. 3, pp. 169, I94; and the various drafts and discussions of the International Law Association, which are published in INTERnational Law Association, Report of tHe 34th Conference 48x, 707, 718 (Vienna 1926), (Vienna Rules), and Report of THE 35TH Conference 44, 271 and 437 (Warsaw 1928), (Draft International Rules on C. I. F. Contracts), and pp. I35 and 293 (Sales); of splecial interest is the expression 
special Committee, presided over by Professor Algot Bagge of Sweden, when the Conference itself had been unable to reach agreement on the delicate topic. Since the draft Convention is brief and full of ideas suggestive for the purposes of the Uniform Commercial Code, it may not be amiss to reproduce in an Appendix to this article the text, which seems to be little known in this country. ${ }^{47}$

In the field of negotiable instruments attention should be paid not only to the fundamental work of Professor Lorenzen ${ }^{48}$ and the experiences in British countries with Section 72 of the English Bills of Exchange Act, ${ }^{49}$ but also to The Geneva Convention on Provisions Concerning the Conflict of Laws Relating to Bills of Exchange of $1930,{ }^{50}$ and the Geneva Convention on Provisions Concerning the Conflict of Laws Relating to Checks of $193{ }^{51}{ }^{51}$

Rules attempting to codify the conflict of laws relating to negotiable instruments are also contained in Articles 23-39 of the Treaty on International Commercial Terrestrial Law, signed at Montevideo on March I9, I940. ${ }^{52}$ Provisions touching upon a variety of topics covered in the Uniform Commercial Code can be found in numerous sections of the Pan-American Code of Private International Law (Código Bustamante) of $1928 .^{53}$

3. For all the reasons stated it would seem to be best to drop from the Act all the provisions on its applicability, except those special rules contained in its various Articles on particular transactions and, perhaps, a general clarification of the permissibility and scope of the parties' freedom by their own choice to determine the law of their contract.

a. But even a provision on party autonomy would not be easy to express in statutory language. The problem of party autonomy has been the subject of much controversy in this country and abroad. ${ }^{54}$ In spite of all theoretical objections the courts of practically all countries have shown a remarkable unanimity in recognizing the parties' freedom by themselves to fix the law by which their contract is to be

of the international businessman's point of view in Opinions of the INTERnational Chamber of CoMIIERCE, published on p. 707 of the Report of the $34^{\text {th }}$ and on p. 440 of the Report of the 35 th Conference. In the formation of these Opinions, American business circles exercised a considerable influence.

¿7 Infra p. I40.

18 The Conflict of Laws Relating to Bilis and Notes (19ig).

${ }^{10}$ See A. V. Dicey, Conflict of Laws 678 (6th ed. Morris, 1949); Geoffrey C. Cheshire, Priyate International Law 357 (3d ed. x947); Martin WolfF, Private International LaW 484 (i945); John D. Falconbridge, Essays oN the Conflict of Laws 269 (1947).

${ }^{\circ 0}$ Text in League of Nations Document C. $347(\mathrm{I})$. M. I43(I). I930, II; for a discussion see Hudson and Feller, The International Unification of Laws Covering Bills of Exchange, 44 HARv. L. REv. 333, 370 (I93I); Gutteridge, Unification of the Rules of Conflict Pertaining to Negotiable Instruments, 16 J. COMP. LEG. \& INT'L L. 53 (3d ser. I934).

${ }^{61}$ Text in League of Nations Document C. $194 . \mathrm{M} .77$, I931. B; for a discussion see Feller, The International Unification of Laws Concerning Checks, 45 HARv. L. Rev. 668, 692 (1932).

${ }^{62}$ English text published in 37 AM. J. INT'L L. 37 (I943 Supp.); for a discussion, see Rabel, Revision of the Treaties of Montevideo on the Laws of Conflicts, 39 MICr. L. REv. 517 (I94I).

${ }^{3}$ Sections 105-109 (property), I64-174 (obligations in general), I75-186 (contracts in general), $194 / 5$ (sales), 214-2I9 (security interests), 263-273 (negotiable instruments); the English text is published in 4 Hudson, International Legislation 2279, No. 186.

s4 See 2 Rabel, Confitct of Laws 357 (I948). 
"governed." Wisely, the draftsmen of the Code have followed suit. The determination of the law of the contract by the parties themselves is the surest way to avoid uncertainty on a point that may well be vital and that otherwise might result in disastrous litigation.

As to the permissible scope of the parties' stipulatio iuris, we find in this country and in England a controversy as to whether or not the parties' choice shall be limited to the laws of those jurisdictions with which the contract has some actual contact. That problem would seem to be a purely academic one, however, provided it is made clear that the contact required must not necessarily be one of those which are traditionally resorted to in the conflict of laws. Parties to a sale may have good reasons, for instance, to subject their contract to the law of the place of the insurer of the goods, or of the place where the commerce in the commodity in question is centered. It may thus be desirable to express such possibility more clearly in the Act than it is now.

While it may appear doubtful whether the parties should be generally restricted in their choice to the laws of a limited number of jurisdictions, it may well be advisable to establish topical limits to the parties' freedom of choice. The task of formulating all such limits would be a formidable one, however. In continental theory as well as in England it is frequently said that party autonomy can, or ought to, be permissible only within the sphere of freedom of contract as allowed by the proper law of the contract, but that the parties may not eliminate by their own fiat the mandatory norms of that law. Occasional expressions of this thought can also be found in this country. ${ }^{55}$ That idea is based upon the assumption that there exists for every contract a proper law, so to speak, in the nature of things. That this assumption is fallacious, has been shown repeatedly. ${ }^{50}$ Which law is the proper law of a contract is a question of the conflict of laws. Its rules can be contained only in some legal system superior to all or, at least some, local laws, or in the system of the forum. A legal system containing conflicts rules for contracts, that would be superior to the laws of the sovereign nations of the earth, does not exist at the present time. So far as the states of the Union are concerned, it might be possible that rules superior to state conflicts law might be contained in federal law, especially in the Constitution of the United States. After a short-lived effort to discover such.rules in the due process clause of the Fourteenth Amendment and the full faith and credit clause, the Supreme Court has now taken the position that conflicts law is state law, ${ }^{57}$ subject to federal control only to the extent of preventing flagrant abuses or of taking care of certain narrowly defined special needs. ${ }^{68}$ At present, conflict of laws is thus local law both in international and interstate rela-

${ }^{85}$ Id. at 394; Cheshire, InTERnattonal Contracts (1949).

"6 Raber, op. cit. supra, at 427; Rheinstein, Review of Falcondridge, Essays on the Conflict of Laws, 15 U. of CH. L. Rivv. 478, 484 (1948); Mann, The Proper Law of the Contract, 3 InT'L L. Q. 60 (1950). (1941).

${ }^{57} \mathrm{Klaxon}$ Co. v. Stentor Electric Mfg. Co., 313 U. S. 487 (1941); Griffin v. McCoach, 313 U. S. 498

${ }^{8}$ See supra pp. II9-I20. 
tions. The only law competent to determine the proper law of a contract is that of the forum. Within the limits of international or interstate decency, that law is thus free to determine the contact determinative of the proper law of a contract. The local law may choose as such contact the place of contracting, or the place of performance, or some other place deemed to be relevant, and it may just as well choose that place which the parties have indicated as relevant for them. No logical or legal difficulties stand in the way of such a determination, and in view of the practical needs of business it is a wise one.

It is quite a separate problem whether the forum ought to limit the parties' freedom of choice for other reasons of wise policy. Where a contract is closely connected with the territory of the forum, it may be found expedient or even necessary to prevent the parties from evading all, or some of, the mandatory norms of the lex fori. A state may or, indeed, should prevent, for instance, parties who reside within it evading its usury laws by the simple expedient of stipulating a foreign law. In other words, the forum will naturally be anxious to prevent party autonomy from being used to evade its "public policy." It should be remembered, however, that the forum does not have a legitimate interest to enforce its public policy except with respect to transactions which have a real bearing upon its economy or social structure. The Supreme Court thus properly prevented the application of a Texas statute to a contract devoid of all Texan contacts, even though Texas regarded the statute as expressive of an important Texas public policy. ${ }^{59}$.

It is again a different question to what extent, if any, a state should try to prevent the evasion of an important public policy of another state or country. Obviously, that question should be raised only where there exists such a real contact between the contract and the state or country in question that a violation of that state's or country's laws would appreciably affect its economy or social structure. Such mechanical contacts as place of contracting or place of performance are of little help in this respect. But even where the foreign state or country might be actually affected, the forum's decision will be guided primarily by political considerations. An American state may be more concerned about impairments of the economy or social structure of a sister state or a friendly foreign nation than about a foreign nation showing hostility towards, or being at war with, the United States; and even in the relations among themselves the states of the Union have often shown a marked disregard for each other's public policies-vide Reno divorces, Delaware corporations, and the states' general refusal to enforce each other's revenue laws.

The parties' freedom of choosing the law of their contract should be restricted in one further respect. There are cases in which the law of the contract is chosen not by both parties but by the one who is strong enough to impose his choice upon the other. Obviously, in such situations the stronger party will choose the law that he regards as the most advantageous to him, especially one that will exclude protections

${ }^{50}$ Home Insurance Co. v. Dick, supra note I2. 
that might be available to the weaker party under some other law. Such an abuse of party autonomy should not be tolerated.

' A further problem arises with respect to the applicability of the parties' choice of law to problems of the very validity of the contract. The stipulatio iuris usually appears as a clause in a more extensive contractual instrument. How can that clause be valid if the entire contract is invalid? How can that clause be resorted to when the very litigation turns about the validity of the contract? Legal theory has tried to deal with the problem in various ways, either by exempting the problems of contractual validity from the sphere of party autonomy and subjecting them to a "proper law" chosen by objective criteria, or by applying the internal contract law of the forum. ${ }^{60}$ However, the logical difficulty is more apparent than real. It arises only if the stipulatio juris is regarded as a contractual transaction or as a part of a contractual transaction, a "connecting contract," which is effective only if it fulfills all the requirements of a contract in the technical sense of the word.

However, if the conflicts law of the forum uses the parties' determination of the lex contractus as a contact, it refers to this in a special sense just as it may refer to place of contracting, place of performance, residence, or place of wrong. The forum can and must make its own definition of all such terms; it must define what it means when it speaks of "agreement of" or "determination by" the parties. If it so chooses, the forum's conflicts law might define these expressions in terms of its own internal law of contracts, or it may choose to refer to the contracts rules of the place of contracting or some other place. However, any such reference would be incongruous with the rationale underlying the very recognition of party autonomy. In all countries party autonomy is recognized because it results in the application to contractual problems of the law which the parties had before their minds when they made, or attempted to make, their contract. It is this law the application of which will most certainly correspond to the parties' expectations and calculations and will thus avoid unpleasant surprises more certainly than any other. The term "law agreed upon by the parties" is but an imperfect expression of what really counts, viz., "the law which the parties had before their minds when they made, or attempted to make, their contract." If so understood, the problem of how to apply the law "agreed upon" by the parties to questions concerning the very validity of this "agreement," disappears, or rather reveals itself as an apparent rather than a real problem. But there appears in its stead another problem, viz., that of determining which law, if any, the parties had before their minds at the relevant time. This problem is a factual one, but it must not be obscured by a statutory text. That, however, is exactly the case when the statute says that the parties may "agree" upon a certain law.

Such a formulation may also induce one or both of two equally inappropriate ideas, both of which have frequently misled legal thought. The first of these ideas

${ }^{80}$ Bajic, The Connecting Contract, 3 Cakters de Frontenex I, 12 (1947). 
is that, in order to be effective, the "agreement" of the parties must be express, i.e., clearly stated in so many words in some clause of the contract. The other idea is the very opposite, viz., that of searching for and finding an "implied" agreement in cases where actually the parties, or one of them, had no ideas at all with respect to the law under which possible future controversies might have to be decided. Few ideas have resulted in so much mischief as this. Either the parties, i.e., necessarily both, had some law before their minds, or they had not. In the former case that law should be applied; in the latter the contract must be tied to some legal system by some objective criteria. On the other hand, there is no reason why the parties' consonant ideas as to the law of their contract ought to be express, as long as they can at all be ascertained by means of proof regarded to be sufficient and appropriate by the forum.

It should be clear by now that it would be a difficult and delicate task to express in statutory language all the considerations just stated. None of the policies indicated can be effectively pursued by a mechanical limitation of the parties' choice to the laws of those jurisdictions with which their contract has actual contacts.

The observance of the forum's public policy can be achieved with comparatively least difficulty through the insertion of a proviso, which ought to be so formulated, however, as to exclude the application of the forum's mandatory laws to transactions which do not have a sufficiently close connection with the forum's economy and social structure.

The statutory expression of the policies determinative of a desire of the forum to prevent the "evasion" of important mandatory laws of some foreign state or country presents greater difficulties. In France and other countries following French juristic thought, the term "international public policy (ordre public international)" has been sought to be used for this purpose. It is practically unknown in this country; it would not fit interstate relations, and it is exceedingly vague. Its use can hardly be recommended for the Uniform Commercial Code.

The problem of preventing a party from unduly imposing upon the other a certain choice of law could be taken care of by means of the concept of unconscionableness. Section 2-302 provides that

If the court finds the contract or any clause of the contract to be unconscionable it may refuse to enforce the clause or strike any unconscionable clauses. . . .

At present this provision, being contained in Article 2 of the Act, applies only to sales. If it were transposed to Article $I$, it could be invoked to prevent an unconscionable stipulatio iuris in all types of commercial transactions.

If the Code is at all to contain a provision on party autonomy, something must also be said about those cases where the parties cannot be found to have had any particular law before their minds or those which are not within the scope of their choice. A reference for these cases to the common law rules of conflict of laws would be the simplest solution. If, in addition, the Code is also to contain conflict 
rules of its own for cases not covered by party autonomy, it will be necessary to retain some such provision as is now contained in Sub-Section (7) of the State and SubSection (6) of the Federal Version. However, these provisions must be reformulated, as it would be monstrous, especially in international relations, to apply the lex fori, whenever the transaction has some undefined contact with the forum and the parties have not made a stipulatio iuris.

b. Of the special conflicts provisions contained in the body of the Code, Section 4-I02, protecting a collecting bank against liability for conversion under some law other than that of its own place, has already been mentioned as commendable. If Section I-I05 were retained in any such form as the present one, Section 4-102 would be indispensable.

The same holds true of Sections 9-103 and 10-102, which apply the rule of lex rei sitae to title problems arising out of security transactions and bulk transfers. The former Section also introduces a new and workable approach to the problem of how to deal with security interests created in a chattel while it was in one jurisdiction, which has subsequently been brought into another.

A final problem is suggested by Section II-Io3 which provides that the Article on Documents of Title (Article 7) does not "supersede or modify the provisions of any treaty." Under a generally recognized doctrine an Act of Congress which is incompatible with an existing treaty, supersedes the treaty at least as internal law of the United States. ${ }^{61}$ Thus, if the Code is adopted as an Act of Congress all contradictory treaty provisions are superseded or modified by the Articles of the Act other than Article 7. Is this limitation necessary? Would it not seem wiser, in the interest of the United States in undisturbed foreign relations, expressly to extend the rule of Section II-IO3 to the entire Act?

\section{IV}

While the bulk of the provisions of Section I-105 is concerned with the application of the Act in space, it also undertakes to regulate the Act's application in time in a short phrase which recurs in every one of Sub-Sections (2) to (6) of the State, and (2) to (5) of the Federal Version. It reads as follows:

The Articles on ... apply whenever any contract or transaction within the terms of any one of the Articles is made or occurs after the effective date of this Act....

The seemingly simple provision bristles with problems. They are created by the use of the indefinite word "transaction." 62 If that word were deleted, it would be

${ }^{61}$ Whitney v. Robertson, I24 U. S. 190 (I888).

${ }^{62}$ If a contract to sell is concluded before the effective date of the Act and delivery of the goods is tendered or made after that date, is such tender or such a delivery a "transaction" to which the Act applies, e.g., with respect to the manner of the seller's tender of delivery (2-503), or of shipment by the seller (2-504), or the seller's shipment under reservation (2-505)? Does a financing agency, by making after the effective date of the Act payment or advances against a draft relating to a shipment, acquire the rights stated in Section 2-506, even though the contract to sell was concluded between buyer and seller before the effective date of the Act, or the agreement between the financing agency and the buyer or seller was so made, or the delivery of the goods preceded the payment made by the financing agency? 
clear that the Act is not to apply to any problem arising out of a contract concluded before its effective date. But would such a flat rule be appropriate? There are situations in which application of the new law would not only not work an injustice but would be likely to be expected by the party or parties concerned. Once the Act had gone into effect a buyer might well expect that the new law determines the modalities of his right or duty to inspect the goods and that he has effectively preserved his rights if he has done whatever the new Act requires him to do. He could hardly be expected to inquire in every case of improper delivery whether the contract was made before or after the effective date of the Act and to revert to the formalities of the old law in the former case. On the other hand, it would be irrelevant to the seller whether the buyer follows the formalities of the old or the new law.

Any legislation purporting to regulate the temporal sphere of application of the new Act, would have to take care of all these varying needs and expectations. While the present wording is so ambiguous as to be meaningless, a rule which would compel the application of the pre-Code law to all problems arising out of a pre-Code contract would be too crude.

The drafting of provisions which would take adequate care of all possible problems of intertemporal law would be difficult. However, no express provision seems to be needed at all as the courts have long been dealing with problems of this kind. The vast body of existing case law on problems of retroactivity vel non of new statutes would seem to be a more flexible guide than any oversimplifying legislative text, and thus the most advisable method, again, would be that of saying nothing.

Of all the problems presently dealt with in Section I-I05, there is only one which must be taken care of by express statutory provision, viz., that of determining the scope of application of the Act as a federal law if it were to be adopted by Congress. The Act would then have to say that it is to apply, qua federal law, in all cases which under the common law rules of conflict of laws are to be decided under the law of a federal territory, and to all transactions in or affecting interstate or foreign commerce which, under the common law rules of conflict of laws, are to be decided

Where any improper tender or delivery was rejected by the buyer before the effective date of the Act, may after that date the seller avail himself of Section 2-508 to cure the improper tender? Does the old or the new law regulate the buyer's right or duty to inspect the goods if the contract was made before the effective date of the Act and delivery thereafter (cf. 2-513)?

Does an event occurring after the effective date of the Act and constituting under the Act a breach constinte a "transaction" within the meaning of Section I-105 so that the characterization of the event as a breach vel non and its effects as a breach are determined by the new law?

What about the remedies? What is, for instance, the situation where the contract to sell was made before the effective date of the Act and the buyer's insolvency was discovered by the seller after that date? Does Section 2-702 apply?

Where the contract was made before the effective date of the Act and after that date "the buyer wrongfully rejects or revokes acceptance of goods or fails to make a payment due on or before delivery or repudiates with respect to a part or the whole," are the seller's remedies determined by Section 2-703? Also, which law-the old or the new-determines in this situation whether the buyer's rejection was "wrongful" or whether his conduct amounted to a "repudiation"?

What are the buyer's remedies if, upon a contract concluded before the effective date of the Act, allegedly defective goods are tendered or delivered after that date?

What is the measure of damages for a breach occurring after the effective date in a contract concluded before? 
under the law of the United States of America. As for the rest, silence would be the best policy.

\section{APPENDIX}

Draft Convention on Conflicts of Laws within the Field of Sales of Chattels ${ }^{03}$ Article r. This Convention applies to conflicts of laws in the field of sales of chattels, except sales of ships and other registered vessels, sales of registered aircraft, and sales under judicial authority or sales upon attachment.

For purposes of application of this Convention there are assimilated to sales, contracts for the delivery of chattels to be manufactured or produced, provided the party which binds himself to make delivery has to furnish the materials necessary for the manufacturing or the production of the goods.

Article 2. The sale is governed by the internal law of the country designated by the contracting parties.

This designation must either appear in an express clause or must be clearly apparent from the provisions of the contract. The conditions relating to the parties' consent as to the law applicable are determined by that law.

Article 3. In case of default of a law declared to be applicable by the parties under the conditions provided in the preceding Article, the contract is governed by the internal law of the country where the seller has his habitual residence at the time at which he receives the order. If the order is received by a commercial establishment of the seller, the sale is governed by the law of the country in which this establishment is situated. However, the sale is governed by the internal law of the country in which the buyer has his habitual residence or in which he has the commercial establishment by which the order was made, if it is in that country that the order has been received either by the seller or by his representative, agent, or travelling salesman.

Article 4. If the sale is one made at an exchange or at a public auction, the contract is governed by the internal law of the country in which the exchange is located or in which the auction takes place.

Article 5. Any express clause to the contrary notwithstanding, the internal law of the country in which there has to take place the inspection of the goods delivered by virtue of the sale, applies with respect to the form and the period within which the inspection and notification has to be made as well as with respect to the measures that have to be taken in the case of a refusal of the goods.

Article 6. The present Convention does not apply to conflicts of laws relating to

(r) the capacity of the parties;

(2) the form of the contract;

(3) the transfer of title, with the understanding, however, that the passing of the risk is subject to that law which is applicable by virtue of the present Convention;

(4) the effects of the sale as to any person or persons other than the parties.

Article 7. In every one of the states adhering to the present Convention, the application of the law determined by this Convention may be excluded for reasons of public policy.

es Translated from the French text as published in 7 ZeItschrift FuER AUsLandisches UND INTERnattonales Privatreckr 957 (1933). 